\title{
Highlights in the History of Hydraulics
}

\author{
H U N T E R RO USE
}

If the word hydraulics is understood to mean the use of water for the benefit of mankind, then its practice must be considered to be even older than recorded history itself. Traces of irrigation canals from prehistoric times still exist in Egypt and Mesopotamia; the Nile is known to have been dammed at Memphis some six thousand years ago to provide the necessary water supply, and the Euphrates River was diverted into the Tigris even earlier for the same purpose. Ancient wells still in existence reach to surprisingly. great depths; and underground aqueducts were bored considerable distances, even through bedrock. In what is now Pakistan, houses were provided with ceramic conduits for water supply and drainage some five thousand years ago; and legend tells of vast flood-control projects in China barely a millenium later. All of this ${ }^{1}$ clearly demonstrates that men must have begun to deal with the flow of water countless millenia before these times.

Though both the art and the science of hydraulics treat of such flows, they obviously differ significantly in time and substance. $\mathrm{Hy}$ draulic practice necessarily originated as an art, for the principles involved could be formulated only after long experience with science in general and water in particular. However necessary the conduct of the art thus was to the eventual development of the science, it is almost exclusively with the science of hydraulics that the present article will deal. As a matter of fact, the subject matter of the traditional college course in hydraulics-particularly as it was taught in the not-too-recent past-provides a framework on which the history of the science can conveniently be based.

Such a course usually began with the topic of hydrostatics-the characteristics of liquids at rest. Instructors then proceeded to the

1 Hunter Rouse and Simon Ince, History of Hydraulics (Iowa City: Institute of Hydraulic Research. 1957). 
principle of continuity (the conservation of fluid mass) and a form of the work-energy principle known as the Bernoulli theorem. In passing, note was taken of means of measuring velocity, pressure, and discharge, including the use of small-scale models to simulate flow conditions in themselves too large to test. These principles were then applied to the study of flow from orifices, over weirs, through closed and open conduits, and past immersed bodies. Simple as such matters now seem when taught, they actually took centuries to understand. Particularly noteworthy is the fact that many such principles were first clarified by men like Isaac Newton whose interests extended far beyond hydraulics itself.

This science actually had its origins some two millenia ago in the course of Greek civilization. It must be granted, however, that Greek physics was of such a hypothetical nature that-with one exceptionit had little positive influence in the millenia to follow. The part that concerns us here is the then-prevailing belief that the universe consists of four elements (fire, air, water, and earth), that each is displaced by the next in order of increasing weight, and that the space around us must be occupied by one element or another. "Nature," in other words, "abhors a vacuum." In due time the concept of a fifth element, ether, came into being, for want of something to fill outer space. To the Greeks, the abhorrence of a vacuum served to explain free flight, a body in motion presumedly being driven by the fluid closing in behind. Known as the medium theory of motion, ${ }^{2}$ this was one of the teachings of Aristotle (384-322 B.C.), who wrote on a wide variety of subjects ranging from physics to metaphysics. The so-called impetus theory of motion was proposed nearly a thousand years after Aristotle's time; ${ }^{3}$ however, because impetus could not be seen, the concept was not generally accepted, and the medium theory remained in favor for at least another millenium.

The Greek who made the most lasting contribution to hydraulics was the Sicilian mathematician Archimedes (287-212 B.C.), who reasoned that a floating or immersed body must be acted upon by an upward force equal to the weight of the liquid that it displaces. ${ }^{4}$ This is the basis of hydrostatics and also of the apocryphal story that Archimedes made this discovery in his bath and forthwith ran unclothed through the streets crying "Eureka!" Nevertheless, even

2 Morris R. Cohen and I. E. Drabkin, A Source Book in Greek Science (New York: McGraw-Hill. 1948).

3 René Dugas. Histoire de la Mécanique (Paris: Editions du Griffon, 1950).

4 Thomas L. Heath, The Works of Archimedes (Cambridge: Cambridge University Press. 1897). 
though Archimedes' writings, like those of his fellow Greeks, were faithfully transmitted to the West by Arabian scientists, further progress in hydrostatics was not to be made for another 18 centuries.

In the course of the millenium following the time of Archimedes, the science of hydraulics retrogressed rather than advanced. True, though the Romans developed extensive water-supply and drainage svstems, and windmills and water wheels appeared on the scene in increasing numbers, these represented the art rather than the science. Paradoxically, although Aristotle taught that knowledge must progress, his teachings eventually came to be crystallized, so to speak, and in the time of Saint Thomas Aquinas (1225-74), they were even adopted as gospel truth by the church. In the same period, on the other hand, researchers in the early universities-particularly Paris, Oxford, and Cambridge-gradually began to establish simple mechanical relationships such as that between velocity and acceleration. ${ }^{5}$

Whereas the Greeks tended to reason without recourse to observation, it was the Italian genius Leonardo da Vinci (1452-1519) who first emphasized the direct study of nature in its many aspects. Leonardo's hydraulic observations extended to the detailed characteristics of jets, waves, and eddies, not to mention the flight of birds and comparable facets of essentially every other field of knowledge. In particular, it was Leonardo who first correctly formulated the basic principle of hydraulics known as continuity: the velocity of flow varies inversely with the cross-sectional area of a stream. Unfortunately, not only were his copious notes written in mirror image (probably for reasons of secrecy), but, in addition, most of them were lost for several centuries after his death. ${ }^{6}$ Thus his discoveries had little effect on the growth of the science.

The second essential contribution to hydrostatics was made by the Dutch hydraulic engineer Simon Stevin (1548-1620) in 1586,7 nearly two millenia after the time of Archimedes. Stevin showed that the force exerted by a liquid on the base of a vessel is equal to the weight of a liquid column extending from the base to the free surface. That this force does not depend on the shape of the vessel became known as the hydrostatic paradox.

If Leonardo was the first scientific observer of note, it was Galileo

5 Pierre Duhem. Etudes sur Léonard de Vinci series 3: Les Précurseurs parisiens de Galilée (Paris: A. Hetmann, 1913).

6 Leonardo da Vinci. Del Moto e Misura dell'Acqua, ed. E. Carusi and A. Favaro (Bologna: N. Zanichelli, 1923).

7 E. J. Dijksterhuis, Simon Stevin (The Hague: M. Nijhoff, 1943). 
(1564-1642) who added experimentation to observation, thereby throwing initial light on the problem of gravitational acceleration. ${ }^{8}$ In his study of the phenomenon, he noted that a body sliding freely down an inclined plane attained a certain speed after a certain vertical descent regardless of the slope; it is said that he hence advised an engineer that there was no point in eliminating river bends, as the resulting increase in slope would have no effect! Whereas Leonardo was a loner, Galileo gathered a small school around him. One of his students, the Abbé Benedetto Castelli (c.1577-c.1644), rediscovered the principle of continuity ${ }^{9}$ and delved further into other aspects of the science, though not always correctly. His younger colleague Evangelista Torricelli (1608-47) applied his mentor's analysis of parabolic free-fall trajectories to the geometry of liquid jets. ${ }^{10}$ Torricelli also experimented with the liquid barometer, the vacuum above the liquid column being comparable to the void that Galileo found to develop in a pump whose suction pipe exceeded a certain length; in other words, nature abhorred a vacuum only up to a certain point!

The French scientist Edme Mariotte (1620-84) is often called the father of French hydraulics because of the breadth of his experimentation; ${ }^{11}$ this included such matters as wind and water pressure and the elasticity of the air, a quality which we usually associate with the name of the Englishman Robert Boyle (1627-91);12 whereas the latter appears to have coined the word hydraulics, in France Boyle's law bears the name of Mariotte. Only a few years younger than Mariotte, the Italian Domenico Guglielmini (1655-1710) is similarly considered by many to have been the founder of the Italian school. But whereas Mariotte was a laboratory experimenter, Guglielmini made extensive field measurements of river flow. ${ }^{13}$ Interestingly enough, Guglielmini eventually became a professor of medicine!

At about the same time, the short-lived French savant Blaise Pascal (1623-62) concerned himself with the same barometric prob-

8 Galileo Galilei. Dialogues Concerning Tuo New Sciences, tr. Henry Crew and A. da Salvio (Chicago: Northwestern University, 1939).

9 Filippo Arredi, "Intorno al trattato 'Della misura dell'acqua correnti" di Benedetto Castelli," Annali dei Lavori Pubblici, no. 2 (1933).

10 William F. Magie. A Source Book in Physics (New York: McGraw-Hill, 1935 ).

11 Edme Mariotte. Traite du Mouvement des eaux et des autres corps fluides (Paris: E. Michallet. 1686).

12 Robert Boyle. New Experiments, Physico-Chemical, second ed. [Oxford: T. Robinsor. 1662].

13 Domenico Guglielmini, Della natura dei fiumi (Bologna: A. Pisarri, 1697). 
lems as the equally short-lived Torricelli (not to mention Mariotte), but it was Pascal who finally completed the principles of hydrostatics. ${ }^{14}$ Not only did he clarify the transmissibility of pressure from point to point and its application to the hydraulic jack, but he also showed that the barometric (i.e., atmospheric) pressure must vary with elevation and hence that the barometer would have a zero reading in a vacuum.

René Descartes (1596-1650), the French scientist to whom we owe the Cartesian coordinate system, sought valiantly to reconcile the Aristotelian teachings that had been adopted by his church with the mechanics of the solar system. He thus hypothesized ${ }^{15}$ that the planets were carried in their orbits by a system of giant vortices endowed with a fixed "quantity of movement." His somewhat younger English contemporary Isaac Newton (1642-1727), who correctly used the principle of momentum to evaluate the orbits, ${ }^{16}$ held that if there were vortex material in space, the motion of the planets would be retarded. Newton even conducted a variety of experiments on the resistance (due to fluid tenacity, elasticity, want of lubricity, and inertia) encountered by bodies in motion to prove that nothing of the sort occurred in space. In the course of these studies, he formulated the speed of sound in air (except for the adiabatic constant), the basis of viscous shear, and the equation of what we now call form drag (except that he mistakenly considered shape itself to be of no importance). He also invented what he termed the theory of fluxions, now known as the calculus.

Newton's German contemporary Gottfried Wilhelm von Leibniz (1646-1716) conceived the principle of energy, ${ }_{17}$ though without the fraction one-half in the kinetic-energy term, and as a result his principle gave different results from Newton's momentum principle when used to describe the same phenomenon. Leibniz also developed a form of the calculus, and his colleagues and Newton's soon began to accuse the other of plagiarism, a dispute which, though largely unjustified, produced a considerable rift between the English and the German scientists.

One of the earliest mathematicians to apply Leibniz's calculus (and even to contribute some of the nomenclature still used today) was the Swiss Johann Bernoulli (1667-1748), who was also note-

14 Blaise Pascal, Traitez de l'équilibre des liqueurs (Paris: G. Desprez, 1663).

15 René Descartes, Principia philosophiae (Amsterdam: L. Elzevir. 1644).

16 Isaac Newton, Philosophiae Naturalis Principia Mathematica (London: Joseph Streat, 1687).

17 Gottfried Wilhelm von Leibniz, Acta Eruditorum (1686). 
worthy for the mathematical training of his son Daniel (1700-82) and his son's comrade Leonhard Euler (1707-83). Johann thereafter went to Paris to collaborate with the French nobleman the Marquis de l'Hôpital; Daniel became a member of the Russian academy at St. Petersburg, where he was later joined by Euler. L'Hôpital eventually published his and Johann's (largely the latter's) joint findings without due credit to his collaborator, much to Johann's chagrin. When Daniel published in 1738 the original treatise Hydrodynamica, ${ }^{18}$ Johann proceeded to write a book that he called Hydraulica, ${ }^{19}$ which-whether through envy or bitterness over l'Hôpital's failure to acknowledge his contribution-he purposely predated a full ten years!

Daniel's work contained much that was new-for example, the use of manometers, the kinetic theory of gases, and jet propulsion-but nowhere in the book (or in his father's either) can one find what is known as the Bernoulli theorem. Just as its source, Leibniz's energy principle, consisted of only potential and kinetic terms, so too did the Bernoulli equation; the corresponding pressure term was evaluated separately by means of Newton's momentum equation.

In actuality, the first true Bernoulli equation was derived by Euler, an outstanding mathematician, from his equations of acceleration for the conditions of steady, irrotational flow under gravitational action. ${ }^{20}$ Euler also deserved credit for a number of equations of hydraulics and for inventing-at least on paper-a workable hydraulic turbine. Worthy of mention in the same breath as Euler and the Bernoullis was Jean Lerond d'Alembert (1717-83), best known for his coeditorship of the French encyclopedia but also a mathematician in his own right. He proved in 1752 that under steady, irrotational conditions a fluid should offer no resistance to the relative motion of an immersed body: the d'Alembert paradox. ${ }^{21}$ D'Alembert is also known for having been one of three French scientists to have made in 1775 what were said to have been the first towing-tank tests of ship-model drag; ${ }^{22}$ they were, however, preceded

18 Daniel Bernoulli. Hydrodynamica (Strasbourg: J. R. Dulseckeri, 1738).

19 Daniel Bernoulli. Hydrodynamica, and Johann Bernoulli, Hydraulica, tr. T. Carmody and H. Kobus (New York: Dover Publications, 1968).

20 L. Euler, "Principes généraux de l'état d'équilibre des fluides;" "Principes généraux du mouvement des fluides;" "Continuation des recherches sur la théorie du mouvement des fluides." Histoire de l'Académie de Berlin (1755).

21 Jean Lerond d'Alembert, Essai d'une nouvelle théorie sur la résistance des fluides (Paris: David l'aine, 1752).

22 Jean Lerond d'Alembert et l'abbé Bossut, Nouvelles expériences sur la résistance des fluides (Paris: C.-A. Jombert, 1777). 

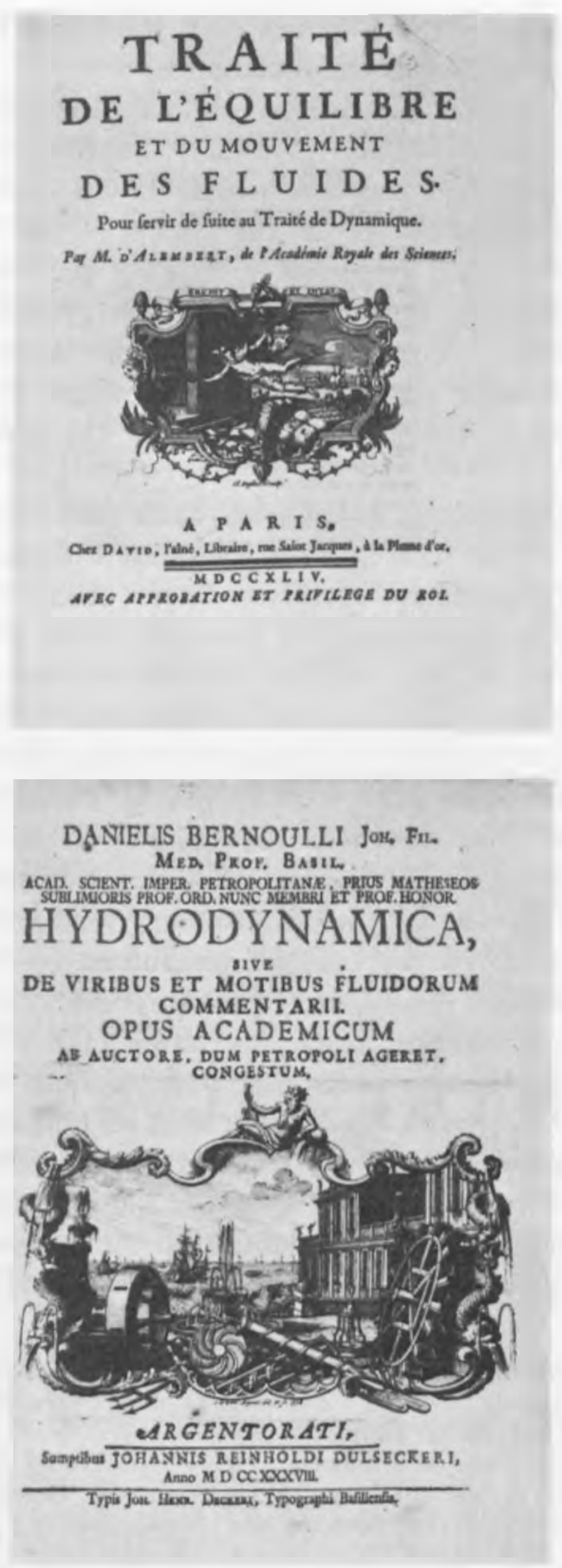

Title pages of two eighteenth-century works from the History of Hydraulics Collection: a treatise by d'Alembert published in Paris in 1744 and a volume by Daniel Bemoulli published in Strasbourg in 1738. 
by some nine years by those of our own Benjamin Franklin (1706$90),{ }^{23}$ himself a potential hydraulician!

Even Franklin was not the first to conduct scale-model tests, credit for which is due John Smeaton (1724-92), an English engineer who was one of the very few practical people in his country to become a member of the Royal Society in the course of the next century or so. In his prize-winning paper of 1759 , "An experimental Inquiry concerning the Natural Powers of Water and Wind to turn Mills, and other Machines, depending on a Circular Motion,"24 Smeaton described experiments on models of undershot wheels, overshot wheels, and windmills, evaluating therefrom the general power relationships.

Two essential measuring instruments came into being at this time, the Pitot tube and the rotating arm. The first still bears the name of its inventor, the Frenchman Henri de Pitot (1695-1771), who called it a "machine" for determining the speed of flowing water. ${ }^{25}$ It consisted of two vertical glass tubes connected at their top by a valve, one tube simply being open at the bottom and the other L-shaped with its open end pointing upstream; the difference in water level between the two tubes after closure of the valve and their withdrawal from the flow permitted the velocity to be computed. Use of a rotating arm to propel a body through air for its drag determination ${ }^{26}$ was developed bv the Englishman Benjamin Robins (170751), who also invented the ballistic pendulum.

The matter of fluid resistance is probably the most important one in the field of hydraulics. Until the latter part of the eighteenth century, little was known about the phenomenon, whether in connection with flow through conduits or around immersed bodies. The d'Alembert paradox, obviously, was of little engineering use. On the other hand, d'Alembert's contemporary Antoine Chézy (1718-98) discovered a simple resistance relationship for streams which is now known by his name. Unfortunately, his report to the Corps des

23 Benjamin Franklin, Letter of 1768 to Sir John Pringle in "Letters and Papers on Philosophical Subjects." Experiments and Observations on Electricity (London: Printed for David Henry, 1769).

24 John Smeaton. "An experimental Inquiry concerning the Natural Power of Water and Wind to turn Mills. and other Machines, depending on a Circular Motion." Philosophical Transactions of the Royal Society of London, vol. 51 (1759).

25 Henri de Pitot, "Description d'une machine pour mesurer la vitesse des eaux et la sillage des vaisseaux," Memoires de l'Ácadémie des Sciences, Paris (1732).

26 Benjamin Robins. Mathematical Tracts, vol. 1 (London: J. Nourse. 1761). 
Ponts et Chaussées on the supply of water to Paris was lost in the files, not to be discovered and publicized till late in the last century by the American Clemens Herschel (1842-1930). ${ }^{27}$ On the other hand, Chézy's fellow countryman Pierre Louis George Du Buat (1734-1809) not only conducted a wide variety of experiments but also wrote an excellent textbook on hydraulics which-in spite of his being forced to flee during the revolution-went through three successively enlarged editions. ${ }^{28} \mathrm{Du}$ Buat formulated perceptively the resistance of closed conduits and was the first to show that the drag of immersed bodies resulted more from the suction produced at the rear than from the pressure exerted at the front.

Granted that the Italians, Germans, and to some degree the English made notable contributions in the course of the eighteenth and nineteenth centuries, the leadership was definitely French, mainly through the influence of the Corps des Ponts et Chaussées, which had been functioning effectively since its founding in 1719. For example, in 1822 Louis Marie Henri Navier (1785-1836), a bridge engineer, was the first to attempt the extension of the Euler equations of acceleration to include the flow of a viscous fluid. Though he did not comprehend the essential mechanism of viscous action, his results 29 were mathematically correct. The same equations were developed with greater comprehension somewhat later by the mathematician Baron Augustin Louis de Cauchy (1789-1857), ${ }^{30}$ next by the mechanician Siméon Denis Poisson (1781-1840), ${ }^{31}$ and finally in 1845 by the Cambridge professor George Gabriel Stokes (1819$1903),{ }^{32}$ the latter eventually applying the equations to the resistance of small spheres. It is significant, however, that in the meantime (1843) a more general form of the equations was developed by Jean-Claude Barré de Saint-Venant (1797-1886) and later found to

27 Clemens Herschel. "On the Origin of the Chézy formula," Journal of the Association of Engineering Societies, vol. 18 (1897).

28 P. L. G. Du Buat. Principes d'hydraulique (Paris: L'imprimérie de monsieur, 1779 ).

29 L. M. H. Navier. "Mémoire sur les lois du mouvement des fluides," Mémoires de l'Académie Royale des Sciences, vol. 6 (1827).

30 Augustin Louis Cauchy, Exercices des mathematics (Paris: DeBure, frères, 1826-30).

31 Siméon Denis Poisson. “Mémoire sur les équations générales d'équilibre et du mouvement des corps solides élastiques et des fluides." Journal de l'Ecole Polytechnique, vol. 13 (1831).

32 G. G. Stokes. "On the Theories of the Internal Friction of Fluids in Motion. and of the Equilibrium and Motion of Elastic Solids," Transactions of the Cambridge Philosophical Society, vol. 9 (1851). 
be applicable not only to the laminar phase of viscous flow but also to that known as fluid turbulence. ${ }^{33}$

In the first half of the nineteenth century, the German Gotthilf Ludwig Hagen (1797-1884) conducted in 1839 some very meticulous measurements of the flow of water in small-diameter tubes, ${ }^{34}$ utilizing the water temperature instead of the viscosity as one of the parameters. A few years later the French physician Jean Louis Poiseuille (1799-1869) repeated the experiments independently, ${ }^{35}$ using even finer tubes to simulate blood vessels, and oil and mercury in addition to water. Except in Germany, the phenomenon is known as Poiseuille flow, even though neither Poiseuille nor Hagen really understood the mathematics of the phenomenon. Hagen, however, had remarked in an 1854 paper ${ }^{36}$ that the flow was not always laminar, the efflux jet sometimes being clear and sometimes frosty; similarly, sawdust suspended in the water sometimes moved in straight lines and sometimes very irregularly; in the latter instances he noted that his resistance equation no longer applied.

Though countless contributors to hydraulic science of this period are to be found in the ever-growing literature, only a few can be mentioned at this point. These include the Italian Giovanni Battista Venturi (1746-1822), ${ }^{37}$ and the Germans Johann Albert Eytelwein (1764-1848) ${ }^{38}$ and Julius Weisbach (1806-71). ${ }^{39}$ In addition to Bernoulli, the men whose names are now best known in hydraulics were two Englishmen who lived in the latter part of the last century. One was the Manchester professor Osborne Reynolds (1842-1912), who in 1873 also experimented with flow through tubes, introducing the viscosity to form a parameter marking the borderline between lam-

33 Barré de Saint-Venant, "Note à joindre au Mémoire sur la dynamique des fluides." Comptes-rendus hebdomadaires des Séances de l'Académie des Sciences, vol. 17 (1843).

34 G. H. L. Hagen. "Ueber die Bewegung des Wassers in engen cylindrischen Röhren," Poggendorfs Annalen der Physik und Chemie, vol. 16 (1839).

35 Jean Louis Poiseuille, "Recherches expérimentales sur le mouvement des liquides dans les tubes de trés petits diamétres." Compte-rendus hebdomadaires des Séances de l'Académie des Sciences (1841).

36 G. H. L. Hagen. "Ueber den Einfluss der Temperatur auf die Bewegung des Wassers in Röhren," Mathematische Abhandlungen der Akademie der Wissenschaften zu Berlin (1854).

37 Giovanni Battista Venturi. Recherches expérimentales sur le principe de communication latérale dans les fluides (Paris: Houel et Ducros. 1797).

38 Johann Albert Eytelwein, Handbuch der Mechanik fester Körper und der Hydraulik (Berlin: F. T. Lagarde. 1801).

${ }^{39}$ Julius Weishach. Lehrbuch der Ingenieur- und Maschinen-Mechanik (Braunschweig: F. Vieweg, 1850-60). 
inar and turbulent flow, ${ }^{40}$ now known as the Reynolds number. Reynolds also showed by the injection of dye the difference between the two states of motion, for which he is given the credit really due Hagen for his work 20 years earlier.

William Froude (1810-79) was a somewhat older contemporary of Reynolds whose interests lay in the field of naval architecture. Froude built himself a towing tank on his own property and in part with his own funds, for the operation of which he had formulated a similarity law for flows under the influence of gravity. This law has come to be known under Froude's name, although it had actually been announced at least 20 years earlier by Ferdinand Reech (1805$80),{ }^{41}$ an Alsatian teaching in a naval college at Paris. But Froude was the first to note the development along the hull of ships ${ }^{42}$ of what came to be known as the boundary layer, a phenomenon of viscous shear which eventually was shown to be a function of the Reynolds number. It is hence only fair to note that Reynolds was the first to utilize the Froude law of similarity in model tests of tidal action in the Mersev estuary. ${ }^{43}$

At the time that hydraulics was becoming an applied science, mathematicians were developing its theoretical counterpart known as hydrodynamics. Ably begun by Euler and d'Alembert, the practice was continued by such equally famous men as Lagrange (1736. 1813), ${ }^{44}$ Laplace (1749-1827), ${ }^{45}$ Helmholtz (1821-94), ${ }^{46}$ Kelvin (1824-1907), ${ }^{47}$ and Rayleigh (1842-1919), ${ }^{48}$ as recorded in the many

40 Oshorne Reynolks. "An Experimental Investigation of the Circumstances which determine whether the Motion of Water shall be direct or sinuous and of the Law of Resistance in Parallel Channels," Philosophical Transactions of the Royal Society, vol. 186 (1894).

$41 \mathrm{~F}$. Reech. Cours de mécanique d'après la nature généralement flexible et élastique des corps (Paris: Carilian-Goeury, 1852).

42 William Froude, "Experiments on the Surface-friction experienced by a Plane moving through Water." British Association for the Advancement of Science, 42nd meeting (1872).

43 Osborne Reynolds, "On Certain Laws Relating to the Regimen of Rivers and Estuaries, and on the Possibility of Experiments on a Small Scale," Third International Navigation Congress, Frankfort (1888).

44 Joseph Louis Lagrange, "Mémoire sur la théorie du mouvement des fluides." Nowveaux Mémoires de l'Académie royale des Sciences et BellesLettres de Berlin (1781).

45 Pierre Simon de Laplace. “Traité de mécanique céleste (Paris: J. B. M. Duprat. 1808-1823).

46 H. L. F. von Helmholtz, Wissenschaftliche Abhandlungen (Leipzig: Barth, 1882-1895).

47 William Thompson, Lord Kelvin. Mathematical and Physical Papers (Cambridge: Cambridge University Press, 1882-1911).

48 J. W. Strutt. Lord Ravleigh, Scientific Papers (Cambridge: Cambridge University Press. 1899-1920). 
editions of the treatise Hydrodynamic ${ }^{49}$ by the Manchester professor Horace Lamb (1849-1934). However, although presumably dealing with the same fluids, the two subjects were far apart, for hydraulics still lacked mathematical rigor, and hydrodynamics, sufficient contact with reality. Thus, when human flight became a likelihood, neither hydraulics nor hydrodynamics could provide a useful scientific basis for the understanding of aerodynamic lift if not of drag.

Fortunately, a new science, the mechanics of fluids, came into being at the hands of Ludwig Prandtl (1875-1953), a German mechanical engineer teaching at the University of Göttingen. He reasoned as early as $1904^{50}$ that relative motion between a fluid and a streamlined boundary could be analyzed in two parts: a thin layer at the boundary providing the viscous resistance to motion, and the fluid outside the boundary layer providing, in accordance with the principles of irrotational flow, the normal forces producing lift. Prandtl, and the many students who passed through his hands, proceeded to formulate the essential principles of airfoil and propeller operation. ${ }^{51}$ At the same time, the general principles of fluid mechanics became the basis of related fields, including hydraulics. In fact, Paul Richard Heinrich Blasius (1873-1970), one of Prandtl's earliest students, not only provided a mathematical basis for boundary-layer drag 52 but also showed as early as 1911 that the resistance to flow through smooth pipes could be expressed in terms of the Reynolds number for both laminar and turbulent flow, ${ }^{53}$ and another-Johann Nikuradse (1894-1979)-experimented extensively on the resistance of rough pipes as well as smooth. ${ }^{54}$

Except for Ben Franklin's miniature towing-tank experiments, all of the advances described in the foregoing pages were made by

49 Horace Lamb. Hydrodynamics (Cambridge: University Press, 1895). Originally published under the title Treatise on the Mathematical Theory of Fluid Motion (Cambridge: Cambridge University Press, 1879).

50 Ludwig Prandtl, "Ueber Flüssigheitsbewegung bei sehr kleiner Reibung." Verhandlung des III. Internationalen Mathematiker Kongresses, Heidelberg, 1904 (Leipzig, 1905).

51 Ludwig Prandtl, Gesammelte Abhandlungen zur angewandten Mechanik, Hydro- und Aerodynamik (Berlin: Springer, 1961).

52 Paul Heinrich Blasius. "Grenzschichten in Flüssigkeiten mit kleiner Reibung." Zeitschrift für Mathematik und Physik, vol. 56, no. I (1908).

53 Blasius. "Das Aehnlichkeitsgesetz bei Reibungsvorgängen in Flüssigkeiten." Forschungsarbeiten auf dem Gebiete des Ingenieurwesens (1913).

54 Johann Nikuradse. "Gesetzimässigkeiten der turbuleuten Strömung in glatten Rohren." Verein deutscher Ingenieure Forschungsheft 356 (1932); "Strömungsgesetze in rauhen Rohren." Verein deutscher Ingenieure Forschungsheft 361 (1933). 
Europeans. As recounted elsewhere, ${ }^{55}$ American hydraulicians gradually became aware of English, French, and eventually German discoveries, utilizing their coefficients and later repeating and extending their experiments. But it was really not until early in the present century that America began to contribute much that was new. To be sure, Professor Felix Klein of Gottingen is said to have been so deeply impressed by the shops and laboratories of our land-grant institutions that he began to employ men as practical as Prandtl. Much of America's accomplishment, however, came about through the Yankee engineer John R. Freeman (1855-1932), ${ }^{56}$ who not only stimulated the foundation of two federal hydraulics laboratories but also established traveling scholarships with three of the leading engineering societies. Most of the Freeman scholars followed the practice of the German civil engineers, who adhered to small-scale model studies based primarily on the Froude criterion of similitude, but three or four gave heed to the teachings of the Prandtl school and stressed the principles of fluid mechanics. America's prime contribution was in fact the broadening of hydraulics science to include both a reasonable degree of analytical rigor and experimental verification of the physical analysis. The advent of wartime exigencies led to an intensification of laboratory activity in at least two institutions, the California Institute of Technology and The University of Iowa, where those who had studied in Europe under Freeman's auspices were in positions of responsibility. Their experiments ranged from torpedo cavitation to ship drag, from the diffusion of smoke and gas by wind to fog dispersal over airplane landing fields, from the throw of fire streams to atmospheric turbulence.

Freeman's indirect role in advancing the science in America was directly abetted by the influence of two naturalized immigrants, Boris Alexandrovitch Bakhmeteff (1880-1951) and Theodor von Kármán (1881-1963). A Russian professor and consulting engineer, Bakhmeteff was sent to the United States as ambassador by Kerensky, after whose fall he formed, with a number of other White Russians, a profitable match factory and taught hydraulics part-time at Columbia University; he also published as an Engineering Societies Monograph $^{57}$ an extended translation of his St. Petersburg disserta-

55 Hunter Rouse, Hydraulics in the United States, 1776-1976 (Iowa City: Institute of Hydraulic Research, 1976).

58 John Ripley Freeman, ed.. Hydraulic Laboratory Practice (New York: American Society of Mechanical Engineers, 1929).

57 Boris Aleksandrovich Bakhmateff, Hydraulics of Open Channels (New York: McGraw-Hill, 1932). 
tion on open-channel flow. A native Hungarian, von Kármán was one of Prandtl's earliest doctoral students and later a very productive professor at Aachen, Germany; with the rise of Hitler, he migrated to $\mathrm{Cal}$ Tech at Pasadena, and then to Washington as air force consultant during the war; he was the first to receive from President Kennedy the new National Medal of Science, and his autobiography ${ }^{58}$ The Wind and Beyond (not to mention the five volumes of his collected writings) makes for absorbing reading.

I had the distinct privilege of knowing all three of these very effective engineering scientists. Not long after the war, moreover, I encouraged one of our own graduate students at Iowa, Simon Ince, to undertake as his doctoral dissertation a review of the developments described in the foregoing pages. This he did; his 1952 dissertation was entitled "A History of Hydraulics to the End of the Eighteenth Century." Later that year I received an appointment as Fulbright research scholar at Grenoble, France, where Pierre Danel, director of the hydraulics laboratory at the Etablissements Neyrpic, had developed a magnificent library that included many of the historical works mentioned herein. With such material at hand, I rewrote and greatly expanded Ince's dissertation, bringing it up to the middle of the present century. This was published as a bilingual supplement to La Houille Blanche, a journal of which Danel was editor, under the title History of Hydraulics and thereafter in book form by the Iowa Institute of Hydraulic Research. ${ }^{59}$

So strong an impression had Danel's collection of source material made upon me that I soon began to purchase similar works for the institute, with the collaboration of the late Frank Hanlin, bibliographer of The University of Iowa Libraries, using funds acquired through the sale of the History and other books written by the institute staff. These were placed in the University Libraries' Special Collections, and at present a catalog of the collection is being prepared for publication. Essentially all of the books cited in these pages are included therein. In fact, some 350 individual items are now at hand-the finest collection that I know to exist on the history of hydraulics.

58 Theodor von Kármán. with Lee Edson, The Wind and Beyond (Boston: Little, Brown, 1967).

59 See note 1. 


\section{The Wind and Beyond}

THEODORE VON KARMÁN

Pioneer in Aviation and Pathfinder in Space

by Theodore von Kármán with Lee Edson

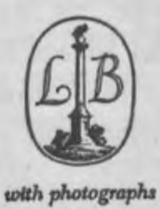

LITTLE, BROWN AND COMPANY - BOSTON - TORONTO

Autobiography (1967) of an engineer whose interests extended into practically every field of mechanics, including fluid mechanics. His autobiography, says Hunter Rouse, "makes for absorbing reading." 